Open Access

\title{
Modeling of URM Infills and Their Effect on Seismic Behavior of RC Frame Buildings
}

\author{
Putul Haldar and Yogendra Singh*
}

Department of Earthquake Engineering, Indian Institute of Technology Roorkee, Roorkee-247667, India

\begin{abstract}
Un-reinforced Masonry (URM) infilled Reinforced Concrete (RC) frames are the most common structural system for multi-storey buildings in India and many other parts of the world. The infills are known to change the behavior and failure pattern of the infilled frames under lateral loading significantly, due to infill-frame interaction. The behavior is further affected by the construction sequence of infilled frames, as the infills are usually added after completion of the frame, and it results in a gap between the infill and soffit of the beam above. This paper presents a macro model for URM infilled frames to simulate the gap and can be implemented on available software. Using the developed model, an analytical study on effect of infills and their construction sequence, on the seismic performance of RC frame buildings designed as per relevant Indian Standards is presented. The infills are modeled as diagonal struts, with stiffness as defined in ASCE 41 and strength in various modes of failure is considered. Nonlinear 'Gap' elements are used to simulate the gap between the infill and the beam and a sequential analysis is performed to take into account the construction sequence of infill panels relative to frames.
\end{abstract}

Keywords: RC frame buildings, URM infills, modeling, construction sequence, capacity curve, nonlinear analysis,

\section{INTRODUCTION}

In the last half century, Reinforced Concrete (RC) frames with Un-Reinforced Masonry (URM) infills have dominated the Indian construction industry, like in many other countries. Despite the fact that URM infills are very inhomogeneous in nature, leading to behavioral complexity and highly unpredictable failure mechanism [1] of infilled frame buildings, URM is the most preferred partition material by the virtue of its mould-ability, effective thermal, moisture, and acoustic insulation properties, ease of construction, and cost effectiveness.

Although, it is widely recognized for long [1-5] that URM infills interact with and modify the seismic behavior of frame buildings, in general design practice, URM infills are treated as non-structural elements and their stiffness, strength, and interaction with frames are often ignored. A number of factors are responsible for this practice, mostly related to the uncertainty and difficulty in simulating the behavior of infilled frames. These include highly variable mechanical properties of infill materials, variable infill-frame interaction leading to complex failure mechanism of infilled frames under lateral loading, absence of computation and time inexpensive modeling guidelines of infills, and moreover the misleading assumption that infills will only provide additional strength and stiffness which will result in improved performance. Ignoring infill-frame interaction does not affect the gravity load resisting system, in which all the gravity loads are resisted only by the frame. However, from the performance of infilled frames in past earthquakes, it is

*Address correspondence to this author at the Department of Earthquake Engineering, Indian Institute of Technology Roorkee, Roorkee-247667, India; Tel: +91-1332-285534; Fax: +91-1332-276899;

E-mail: yogendra.eq@gmail.com evident [6-9] that the behavior of the structure gets totally changed and mostly leads to undesired structural performance in the event of an earthquake. The devastating consequences of the poor performance of infilled frame buildings, even in moderate earthquakes have highlighted the importance of understanding inelastic behavior of infilled frames in context of local construction practices and account for the same in their seismic design.

Infilled frames have been one of the popular topics of research since 1950's as simulation of the behavior of infilled frames is difficult and complex because of infill-frame interaction. Many different modeling techniques for the simulation of the infilled frames are available in literature. The available models can be broadly classified into two categories - micro models and macro models. Micro models are based on finite element representation of each infill panel and thus are able to account for the local infill-frame interaction and to capture the behavior in a much detailed manner. However, the very high degree of non-homogeneity and widely varied non-linear brittle behavior of masonry units and mortar, resulting in time intensive complex computational Finite Element problem, deter its applicability to the practical problems of real structure. The need of simplified models of infills, requiring lesser computational effort with sufficient accuracy has lead to formulation of macro-models. The revolutionary concept of idealizing the diagonal compression action of an infill as diagonal strut(s) within a frame system introduced by Polyakov [10] in 1956 was investigated further by many researchers $[1,11,12]$ and a variety of macro models based on different empirical formulations of diagonal width, strength, and stiffness properties of the strut, were developed over the decades. The details of various macro models can be found in Asteris, et al. [13]. 
Most of the available models consider infills to be constructed simultaneously with the frame and in full contact with adjacent frame members. However, usually the infills are constructed after completion of the frame and this construction sequence does not allow a full contact between infill and soffit of the beam above. The gap between infills and beams can have significant effect on the estimated seismic behavior of infilled frames. This paper presents a macro model for URM infills which can be easily implemented in available software and the model has been used to study the behavior of URM infilled RC frames with due consideration of construction sequence. Case studies are also presented to demonstrate the effect of infill and construction sequence on seismic response of RC frame buildings with varying height and seismic design levels.

\section{CONSTRUCTION SEQUENCE OF INFILLED FRAMES AND ITS EFFECT ON BEHAVIOR}

Traditionally, infill panels in framed buildings are provided after the frame is completed, at least for a few storeys. The construction sequence of infill panels relative to $\mathrm{RC}$ frame, followed in India is shown in Fig. 1. Figs. 1 (a) and 1 (c) show intermediate stages of construction of infill panels in RC frames, whereas Figs. 1 (b) and $\mathbf{1}$ (d) show the final stage. The construction sequence of infilled frame leads to a gap between the infill panel and the beam above. This gap spares the infill panels from resisting any gravity load coming to the frame. Even relatively small initial gap can have significant effect on the structural behavior of infilled frames $[14,15]$. According to Moghaddam and Dowling [16], parameters like initial lack of fit between infill and frame, and workmanship might have even higher impact on the strength of infilled frame than the parameters like strength and stiffness of infills, though these are difficult to be quantified and generalized.

Contrary to the actual sequence of construction, in the conventional 'simultaneous' analysis procedure, the infills and the frame are considered to come to existence instantaneously, and the infills are also subjected to vertical as well as lateral loads, along with the frame members. The application of this fictitious vertical load in the infills may significantly affect their behavior, simulated in a simultaneous analysis. In order to predict realistic behavior of infilled frames, an attempt has been made in the present study to simulate the effect of construction sequence of infilled frames, in non-linear static pushover analysis, where no vertical load is transferred to infills under gravity loading.

To study the effect of the construction sequence on the predicted behavior of the infilled frames, two sets of four and ten storey uniformly infilled RC frame buildings have been considered. The present study is limited to solid uniform infills only. It is well known [17-19] that presence of openings affects the stiffness and strength of infills, significantly. However, the observations made on effect of sequence of construction for solid infills will be largely valid for infills with openings also.

The buildings considered in the study have generic plan geometry as shown in Fig. 2. The plan is symmetric in both directions, but has significantly different redundancy in the two directions. Further, the spans of the beams in the two

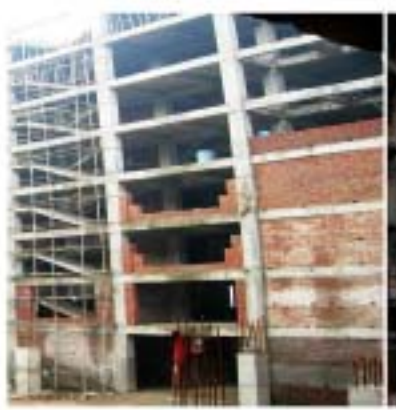

(a)

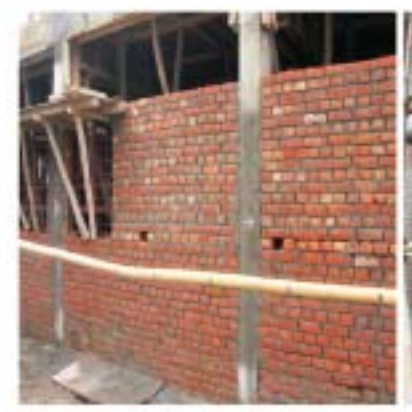

(c)

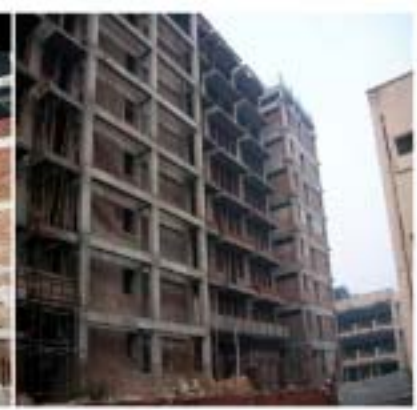

(b)

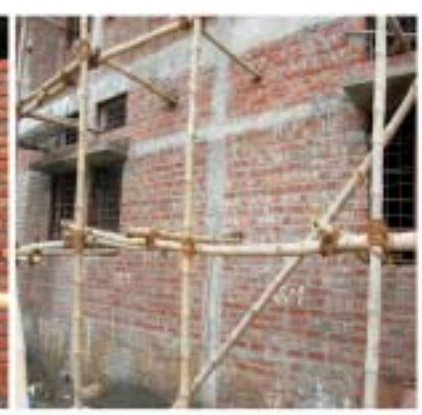

(d)
Fig. (1). Photographs showing typical construction sequence of infilled frame building (c) and (d) show construction of lintel band to prevent out-of-plane failure of infills.

directions are also quite different, representing the characteristics of a wide range of real buildings in India. Table $\mathbf{1}$ summarizes the design and modeling parameters for the considered buildings. The slab thickness is assumed as $150 \mathrm{~mm}$ and a uniform weight of $0.5 \mathrm{kN} / \mathrm{m}^{2}$ has been considered for flooring. The thickness of the infills has been considered as $115 \mathrm{~mm}$ and $230 \mathrm{~mm}$ for interior and exterior partitions, respectively, as per the prevailing practice in India. The first set of four and ten storey buildings are designed for gravity loads only considering relevant Indian Standards [20-22] whereas the second set of buildings are designed for earthquake loading also [23] and reinforcement has been detailed as per the requirement for 'Special Moment Resisting Frame (SMRF)' [24]. Both the sets of buildings have been assumed to be situated on hard soil in seismic zone IV (Effective Peak

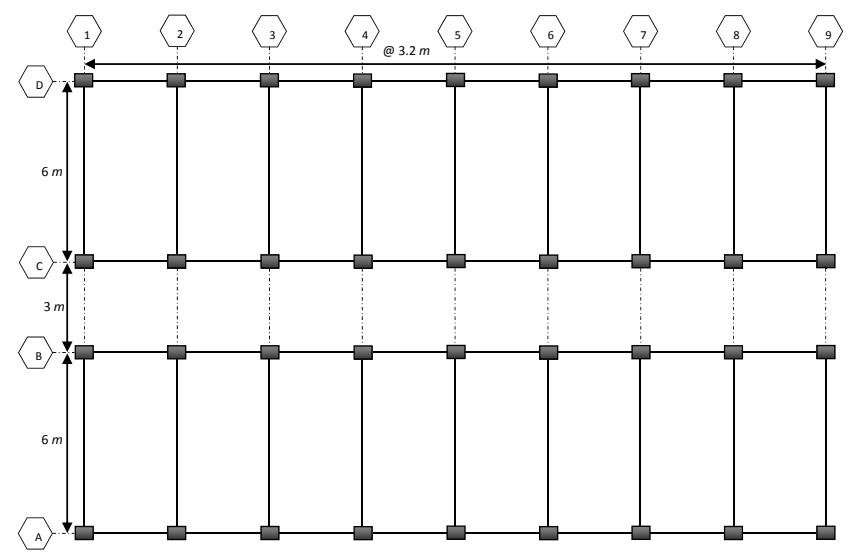

Fig. (2). Plan of the considered buildings. 
Table 1. Design Parameters for the Considered Buildings

\begin{tabular}{|c|c|c|}
\hline \multirow[t]{2}{*}{ General } & Design Levels & $\begin{array}{l}\text { - Bare Frame designed for Gravity Loads } \\
\text { - Infilled Frame designed for Gravity Loads } \\
\text { - Bare SMRF } \\
\text { - Infilled SMRF }\end{array}$ \\
\hline & No. of Stories & 4 and 10 \\
\hline \multirow{4}{*}{ Material } & Concrete & Nominal cube strength $=20 \mathrm{MPa}$ \\
\hline & Steel & Nominal yield strength $=415 \mathrm{MPa}$ \\
\hline & Compressive strength of infill, $f_{c}^{\prime}$ & $4.1 \mathrm{MPa}$ \\
\hline & Modulus of elasticity of infill & $550 f_{c}^{\prime}$ (as per ASCE 41) \\
\hline \multirow{4}{*}{ Loading } & Dead load & $\begin{array}{l}\text { - Self weight of members } \\
\text { - Weight of infill } \\
\text { - Weight of slab and floor finish } \\
\text { - Weight of } 1 \mathrm{~m} \text { high and } 115 \mathrm{~mm} \text { thick masonry parapet wall }\end{array}$ \\
\hline & Live load & $\begin{array}{l}\text { - } 4 \mathrm{kN} / \mathrm{m}^{2} \text { on corridor } \\
\text { - } 3 \mathrm{kN} / \mathrm{m}^{2} \text { on other floor area }\end{array}$ \\
\hline & $\begin{array}{l}\text { Design load combination for gravity } \\
\text { designed buildings }\end{array}$ & 1.5 (Dead load + Live load) \\
\hline & $\begin{array}{l}\text { Design load combinations for SMRF } \\
\text { buildings }\end{array}$ & $\begin{array}{l}\text { - } 1.5(\text { Dead load }+ \text { Live load }) \\
\text { - } 1.2(\text { Dead load }+ \text { Live load } \pm \text { Earthquake load }) \\
\text { - } 1.2(\text { Dead load } \pm \text { Earthquake load }) \\
\text { - } 0.9 \text { Dead load } \pm 1.5 \text { Earthquake load } \\
\end{array}$ \\
\hline \multirow{5}{*}{ Structural modeling } & Software used & SAP2000 Nonlinear \\
\hline & Structure Model & Space frame model \\
\hline & Element models & $\begin{array}{l}\text { - } 3 \mathrm{D} \text { frame elements for beams and columns } \\
\text { - Slabs as rigid diaphragm } \\
\text { - Strut element for infill }\end{array}$ \\
\hline & Plasticity model & Lumped plasticity model based on chord rotation (ASCE 41) \\
\hline & P-delta effect & Considered in pushover analysis \\
\hline
\end{tabular}

Ground Acceleration, EPGA $=0.24 \mathrm{~g}$ for the Maximum Considered Earthquake). Although, buildings should be designed for earthquake loads, throughout India, buildings are still being constructed without any consideration for seismic actions, and there exists a huge stock of such buildings, even in the high seismicity zones. It has been observed in past earthquakes that the frame-infill interaction plays an even important role in such buildings. Therefore, buildings designed for gravity loads alone, have also been considered in the present study. Member sections have been proportioned to have about $2-4 \%$ steel in columns and about $1 \%$ steel (on each face) in beams, wherever permitted by other code requirements.

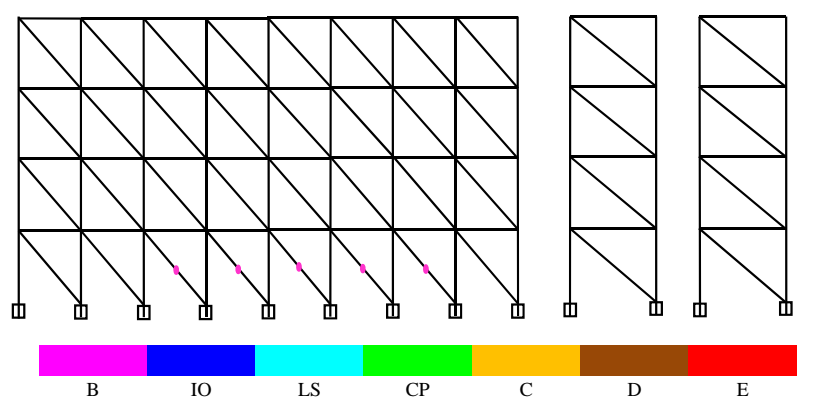

(a)

(b)

Fig. (3). Yield pattern under gravity load for the four storey uniformly infilled frame building, designed for gravity loads only, when construction sequence is not considered in analysis: (a) typical longitudinal frame; (b) typical transverse frame

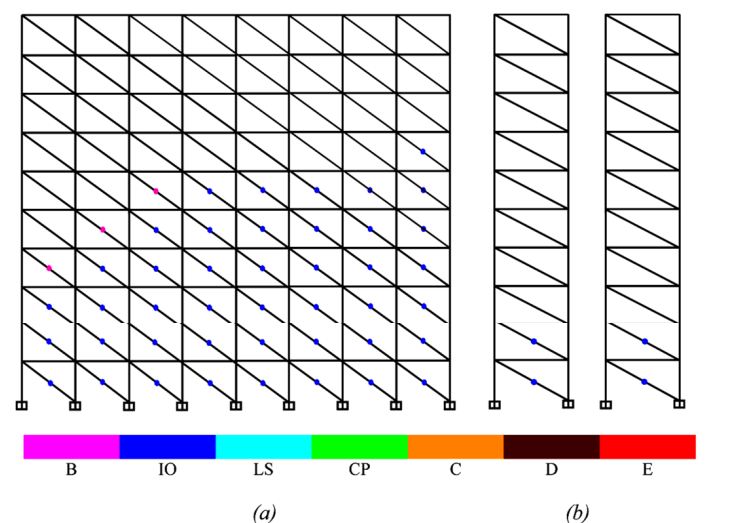

Fig. (4). Yield pattern under gravity load for ten storey uniformly infilled frame building, designed for gravity loads only, when construction sequence is not considered in analysis: (a) typical longitudinal frame; (b) typical transverse frame.

Figs. (3 and 4) show the yielding pattern of the infill panels in the four and ten storey gravity load designed buildings, respectively, subjected to gravity load alone, when the initial gap between infill and frame is not considered in the modeling. It can be observed from the Figs. that some of the infill panels in the longitudinal direction, in the bottom storey of the four storey building have yielded under the gravity load itself. In case of the ten storey building, the effect is even more pronounced, where all the infill panels in the bottom three storeys in longitudinal direction, and the bottom two storeys in transverse direction, have crossed "Immediate 
Occupancy" (IO) performance level [25]. Similarly, Figs. (5 and 6) show the yield pattern of the infill panels in the four and ten storey buildings, respectively, designed for earthquake loads. The buildings are subjected to gravity load alone and the construction sequence has not been considered. Similar behavior is observed in this case also, except that the number of panels yielding under gravity load reduces due to relative increase in the size of frame members in case of buildings designed for earthquake forces. This behavior is contradictory to the common observation and understanding that the infills do not share gravity loads. Therefore, there is need to simulate the construction sequence in the analysis of infilled frames to get realistic results.

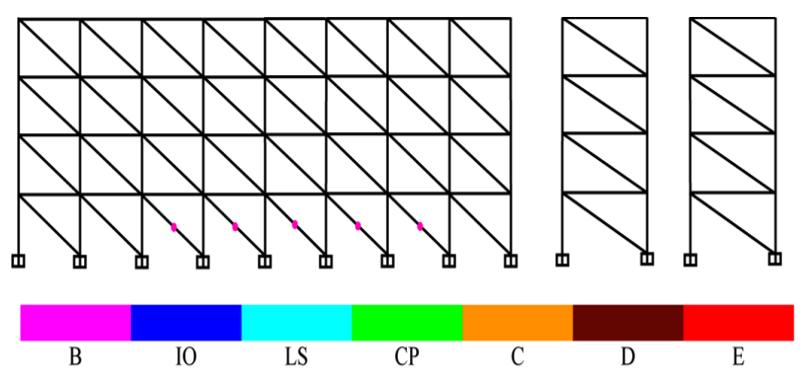

(a)

(b)

Fig. (5). Yield pattern under gravity load for four storey uniformly infilled SMRF building when construction sequence is considered in analysis: (a) typical longitudinal frame; (b) typical transverse frame

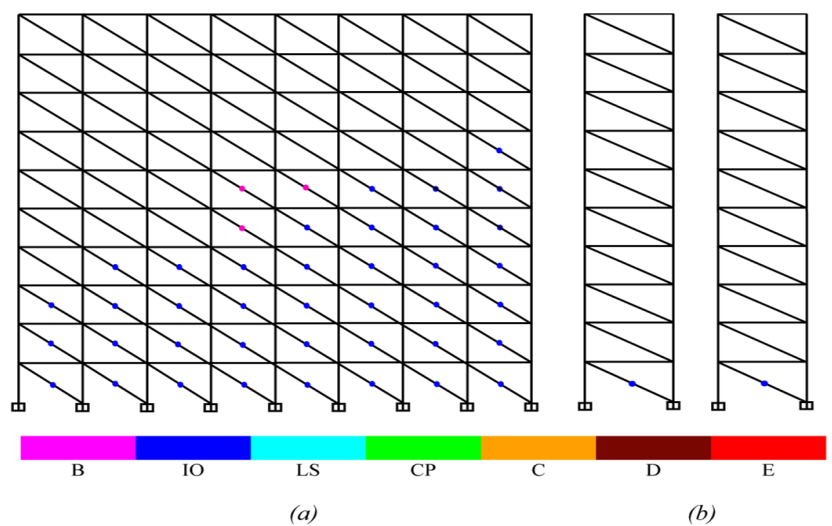

Fig. (6). Yield pattern under gravity load for ten storey uniformly infilled SMRF building, when construction sequence is considered in analysis: (a) typical longitudinal frame; (b) typical transverse frame

\section{PROPOSED MODELLING OF URM INFILLS}

Past studies [11, 25-27] have shown that the equivalent strut models provide sufficiently accurate results for frame infills. Accordingly, in this present study, an equivalent concentric diagonal compressive strut element has been used to simulate the infill panels. To simulate the effect of initial lack of fit between infield panel and beam, 'gap' elements have been used. In presence of gap elements, the struts are active in compression only. Since the 'gap' element is active in nonlinear analysis only, the stiffness of the gap elements has been assigned in such a way that it will not affect the linear and nonlinear stiffness of the infilled frame. In linear analysis, the action of strut with gap element is shown in Fig. (7a), where one brace is inactive due to zero stiffness of gap element. Similarly, the action of struts with gap elements in nonlinear analysis is shown in Fig. (7b), where the gap element is ineffective in tension.

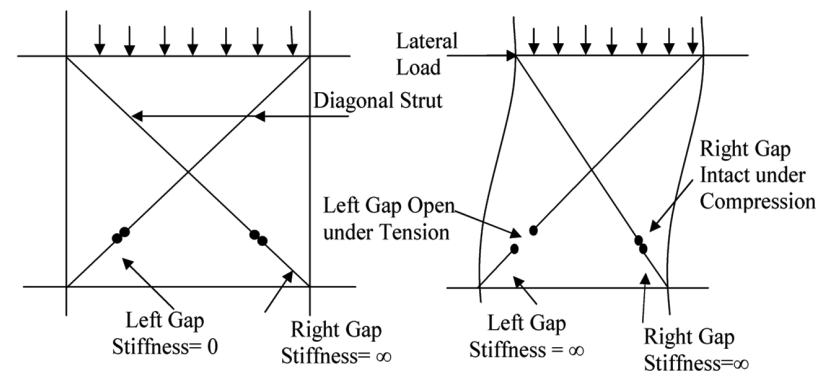

(a)

(b)

Fig. (7). Proposed model of infill panel for: (a) linear analysis; (b) non- linear analysis.

The thickness and modulus of elasticity of the equivalent strut are considered to be the same as those of the infills and the width of the equivalent strut is estimated as per ASCE 41 [25]. In nonlinear analysis, in addition to the stiffness, strength and ductility of infills also need to be simulated. The strength and nonlinear load - deformation behavior of strut member have also been simulated as per ASCE 41 guidelines. The strength of each strut member is calculated based on the minimum strength in all possible failure modes described in ASCE 41. The nonlinear deformations in each strut element have been considered by providing axial plastic hinges as per the recommendations of ASCE 41.

\section{EFFECT OF CONSTRUCTION SEQUENCE ON THE SEISMIC PERFORMANCE OF URM INFILLED RC FRAMES}

To study the effect of construction sequence of infill panels on the estimated behavior of infilled frames, a comparative study on the two sets of four and ten storey buildings, described earlier, has been performed. Both the sets of the buildings have been analyzed for lateral loads due to earthquake with and without considering the construction sequence of infills. To simulate the construction sequence, the analysis has been done in two stages. In the first stage the bare frame has been subjected to gravity load. In the second stage, the infills are added and lateral load is applied along with the existing gravity load. The buildings have also been analyzed neglecting the stiffness and strength of infills (i.e. considering the buildings as bare frames), as is the case in normal course of design. Nonlinear static (pushover) analysis has been carried out using nonlinear analysis software SAP2000 [28] to estimate the capacity curves of the buildings in different cases. Non-conforming, 'NC' and conforming, ' $\mathrm{C}$ ' type of transverse reinforcement has been considered for gravity designed and SMRF infilled frames, respectively, to assign the plastic rotations for beams and columns as per ASCE 41 [25]. Table 2 shows the effect of infills and construction sequence, by comparing stiffness and strength of different buildings with and without infills. 
Table 2. Effect of Infill and Construction Sequence on Strength and Stiffness of RC Frames

\begin{tabular}{|c|c|c|c|c|c|c|}
\hline \multirow[t]{2}{*}{ Design Level } & \multirow[t]{2}{*}{ Frame Configuration } & \multirow[t]{2}{*}{ No. of Storeys } & \multicolumn{2}{|c|}{$\begin{array}{c}\text { Strength } \\
(k N)\end{array}$} & \multicolumn{2}{|c|}{$\begin{array}{c}\text { Stiffness } \\
(k N / m)\end{array}$} \\
\hline & & & Longitudinal & Transverse & Longitudinal & Transverse \\
\hline \multirow{2}{*}{ Gravity Designed } & Bare & \multirow{2}{*}{4} & 811.45 & 1205.11 & 96.38 & 253.55 \\
\hline & Infilled & & 4208.58 & 3988.88 & 12563.96 & 17225.62 \\
\hline \multirow{2}{*}{ SMRF } & Bare & \multirow{2}{*}{4} & 1701.28 & 2063.33 & 11370.86 & 11692.78 \\
\hline & Infilled & & 4941.25 & 4450.57 & 1695052.00 & 1301815.00 \\
\hline SMRF & Bare & 10 & 2036.95 & 1664.32 & 7124.74 & 4438.53 \\
\hline
\end{tabular}

Figs. (8) and (9) compare the capacity curves of the four storey and ten storey gravity designed bare and uniformly infilled frames with and without considering the construction sequence. It can be observed that the infills have very significant effect on capacity curves of the buildings. The stiffness of the building increases 130 times and 68 times and strength increases 5.2 times and 3.3 times in the longitudinal and transverse directions, respectively, in case of the four storey building. In case of the ten storey building, the increase in stiffness is 14.6 times and 36.7 times, and increase in strength is 4.7 times and 2.5 times, in the longitudinal and transverse directions, respectively. However, the inelastic deformation capacity of the infilled frame decreases drastically. The sharp saw-tooth curve in case of ten storey infilled frame building shows the sudden drop in the lateral force due to failure of a set of infills, and quick re-gains in lateral force with displacement, due to high stiffness of the infills.

The effect of construction sequence of infill panels on the capacity curves of four and ten storey infilled frames can also be observed from the Figs. (8 and 9), respectively. In case of the four storey gravity designed buildings, the effect of construction sequence is relatively small and the capacity curve is close to the case when construction sequence is ignored, whereas in case of the ten storey building, the effect of construction sequence is so dramatic that the capacity curve in the longitudinal direction is close to that of the bare frame. This is because in case of four storey building, no infill panel in transverse direction and a very few infill panels in longitudinal direction (Fig. 3), yielded under gravity load, whereas in case of the ten storey buildings, a large number of infill panels (particularly in the longitudinal direction) yielded under gravity load itself (Fig. 4).

The comparison of capacity curves of the four and ten storey SMRF buildings is presented in Figs. (10 and 11), respectively. As the buildings are designed for earthquake forces also, the strength and ductility increases as compared to the gravity load designed buildings. Further, as the stiffness and strength of the frame members increases relative to the infills, the effect of infills on capacity curve reduces. In this case, the stiffness and strength of the infilled frame is 149 times and 2.9 times, respectively of the bare frame in the longitudinal direction, and 111 times and 2.2 times, respectively, in the transverse direction, for the four storey building. In case of the ten storey building, these values are 14.6 times and 2.8 times, respectively in longitudinal direction and 37 times and 2.9 times, respectively in the transverse direction. The effect of construction sequence of infill panels on the capacity curves of the four and ten storey SMRF buildings is similar as in case of the corresponding gravity load designed buildings.

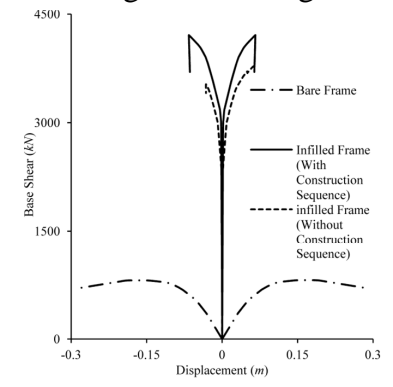

(a)

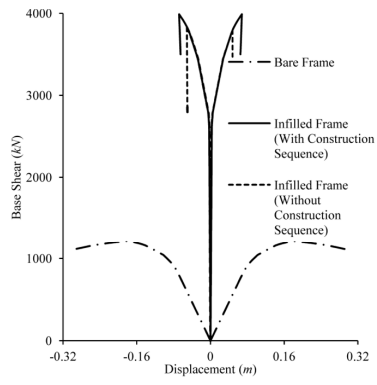

(b)
Fig. (8). Comparison of capacity curves of bare frame and uniformly infilled frame for the four storey building designed for gravity load only: (a) Longitudinal Direction; (b) Transverse Direction

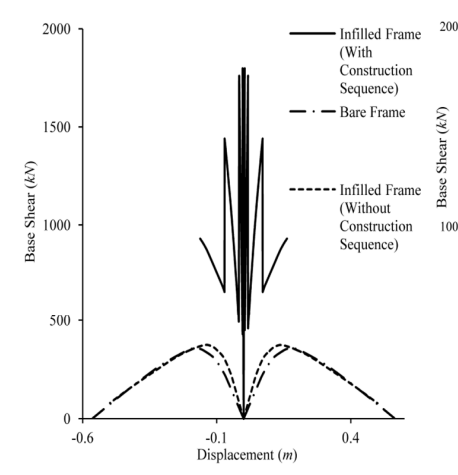

(a)

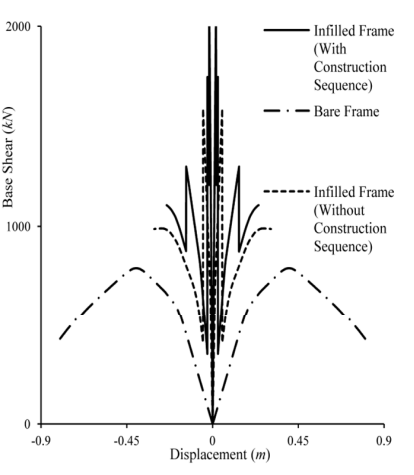

(b)
Fig. (9). Comparison of capacity curves of bare frame and uniformly infilled frame for the ten storey building designed for gravity load only: (a) Longitudinal Direction; (b) Transverse Direction 


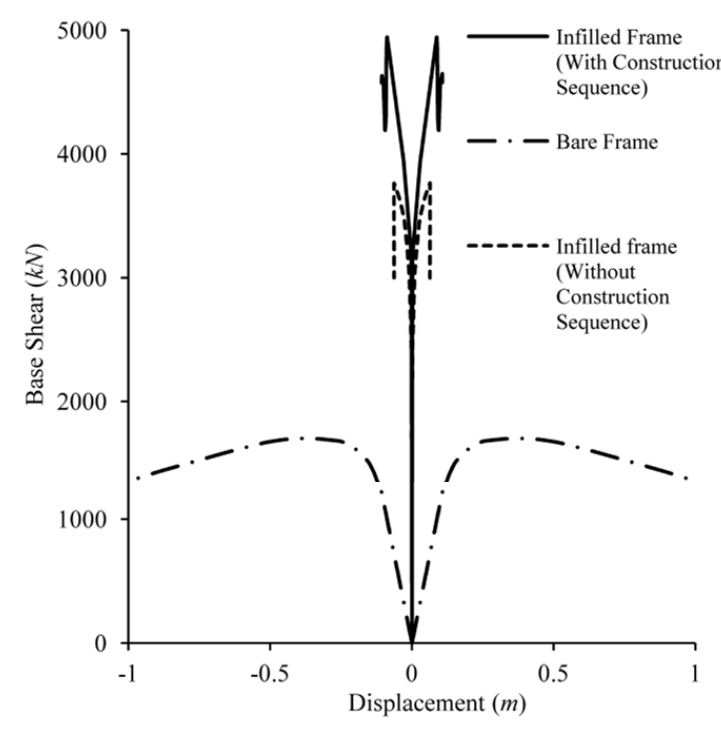

(a)

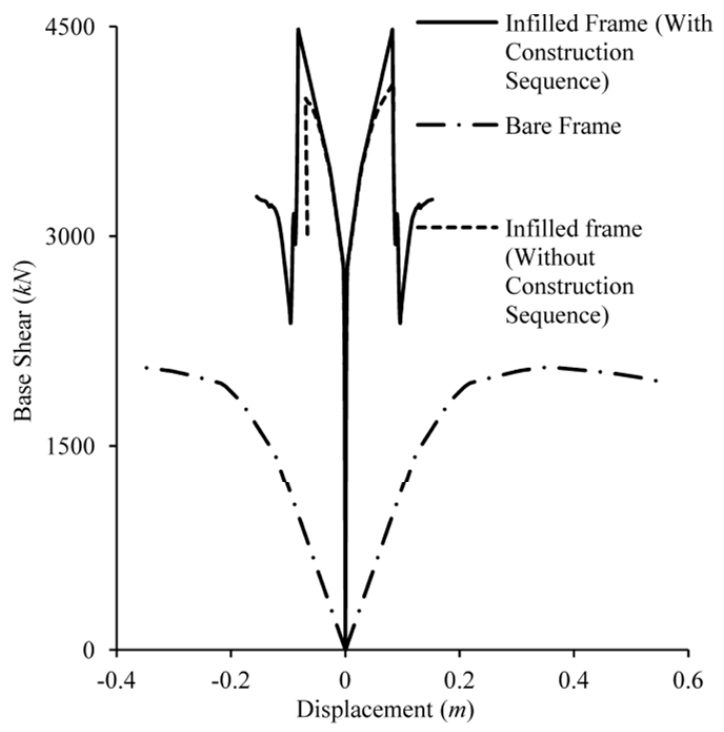

(b)

Fig. (10). Comparison of capacity curves of bare frame and uniformly infilled frame for the four storey building designed as SMRF: (a) Longitudinal Direction; (b) Transverse Direction.

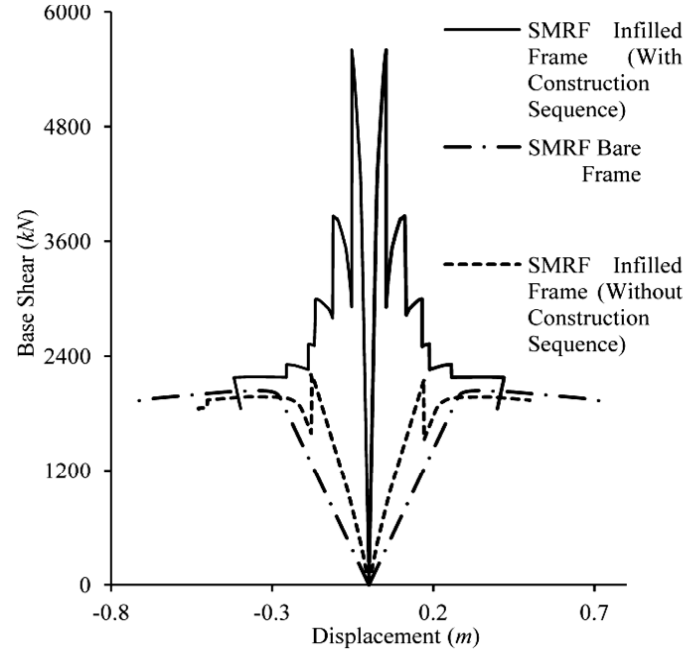

(a)

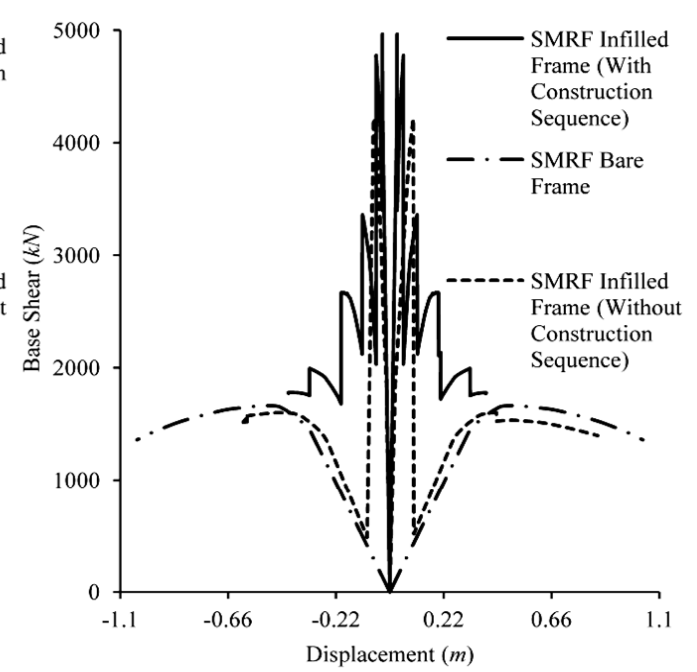

(b)

Fig. (11). Comparison of capacity curves of bare frame and uniformly infilled frame for the ten storey building designed as SMRF, as per relevant Indian Standards (IS 456, 2000; IS 875 Part1 and Part 2, 1987; IS 1893, 2002; IS 13920, 1993) (a) Longitudinal Direction; (b) Transverse Direction

\section{CONCLUSIONS}

A macro model for simulation of the URM infill panels with initial lack of fit has been presented. This model can be easily implemented on available software for nonlinear analysis. Using the developed model, an analytical study has been carried out on four and ten storey buildings to study the effect of infills on the seismic performance of URM infilled RC frame buildings. It has been observed that infills have drastic effect on capacity curves of the infilled frames and their stiffness and strength has been found to increase up to 149 times and 5.2 times, respectively as compared to the bare frames for the studied buildings. Further, simulation of construction sequence of infills relative to frame also has a drastic impact on the estimated capacity curves of the infilled frames and this effect increases with the height of the building. The conventional simultaneous analysis ignoring the construction sequence may be highly erroneous in some cases, and it has been found to almost nullify the effect of infills in longitudinal direction of the ten storey building, considered in the present study.

\section{ACKNOWLEDGEMENT}

Declared none. 


\section{CONFLICT OF INTEREST}

The authors confirm that this article has no conflicts of interest.

\section{REFERENCES}

[1] T. Paulay, and M. J. N. Priestley, Seismic Design of Reinforced Concrete and Masonry Buildings. New York, USA.: John Wiley \& Sons, 1992.

[2] B. Stafford-Smith, "Behaviour of square infilled frames," J. Struct. Div., ASCE, vol. 92(ST1), pp. 381-403, 1966.

[3] A.B. Schriver, J.L. Dawe, and C. Sofocleous, "Dynamic loading of brick panel infills," Proceedings of 5th Canadian Masonry Symposium, pp. 415-424, 1989.

[4] H. Singh, D.K. Paul, and V.V. Sastry, "Inelastic dynamic response of reinforced concrete infilled frames," Comput. Struct., vol. 69, pp. 685-693, 1998.

[5] M.K. Sahota, and J.R. Riddington, "Experimental investigation into using lead to reduce vertical load transfer in infilled frames," Eng. Struct., vol. 23, pp. 94-101, 2001.

[6] GSI, "Report on Uttarkashi earthquake (20th October 1991)," Geological Society of India (GSI), Memoir 30, Bangalore, India, 1995.

[7] DEQ, "A report on Chamoli earthquake of March 29, 1999," Department of Earthquake Engineering, University of Roorkee, Roorkee, India, 1999.

[8] GSI, "Kutch (Bhuj) earthquake 26 January 2001," Geological Survey of India Lucknow, India, 2003.

[9] EERI, "Bhuj, India earthquake of January 26, 2001 Reconnaissance report," Earthquake Engineering Research Institute, 2002.

[10] S.V. Polyakov, "On the interaction between masonry filler walls and enclosing frame when loaded in the plane of the wall," Earthquake Engineering Research Institute, Moscow, 1956.

[11] B. Stafford-Smith, "Lateral stiffness of infilled frames," J. Struct. Div., ASCE, vol. 88, pp. 183-199, 1962.

[12] T.C. Liauw, and K.H. Kwan, "New developments in research on infilled frames," presented at the Proceedings of the 8th World Conference on Earthquake Engineering, San Fransisco, 1984.

[13] P.G. Asteris, S.T. Antoniou, D.S. Sophianopoulos, and C.Z. Chrysostomou, "Mathematical Macromodeling of Infilled Frames: State of the Art," J. Struct. Eng. ASCE, vol. 137, pp. 1508-1517, 2011.

[14] J.R. Riddington, "The Influence of Initial Gaps on Infilled Frame Behavior," Proceedings of the Institution of Civil Engineers, vol. part 2, pp. 295-310, 1984.
[15] A. Saneinejad, and B. Hobbs, "Inelastic design of infilled frames," J. Struct. Eng. ASCE, vol. 121, pp. 634-650, 1995.

[16] H.A. Moghaddam, and P.J. Dowling, "The state of the art in infilled frames," Civil Engineering Department, Imperial College, ESEE Research Report No 87-2, London, 1987.

[17] P.G. Asteris, D.J. Kakaletsis, C.Z. Chrysostomou, and E.E. Smyrou, "Failure modes of infilled frames," Electron. J. Struct. Eng., vol. 11, pp. 11-20, 2011.

[18] H.B. Kaushik, D.C. Rai, and S.K. Jain, "Code approaches to seismic design of masonry-infilled reinforced concrete frames: a state-of-the-art review," Earthquake Spectra, vol. 22, pp. 961-983, 2006.

[19] M.O. EISeify, M.M. EI-Attar, A.M. Ragab, and O.A. Hodhod, "Modelling of opening in masonry infill panels in R.C. frames, 2D approach," HBRC J, vol. 2, pp. 36-49, 2006.

[20] BIS-2000, IS 456 Indian Standard Plain and Reinforced ConcreteCode of Practice (Fourth Revision). New Delhi: Bureau of Indian Standards, 2000.

[21] BIS, IS: 875 (Part 2) Indian Standard Code of Practice for Design Loads (Other than Earthquake) for Buildings and Structures. New Delhi: Bureau of Indian Standards, 1987.

[22] BIS, IS: 875 (Part 1) Indian Standard Code of Practice for Design Loads (Other than Earthquake) for Buildings and Structures. New Delhi: Bureau of Indian Standards, 1987.

[23] BIS, IS 1893 (Part 1) Indian Standard Criteria for Earthquake Resistant Design of Structures. New Delhi: Bureau of Indian Standards, 2002.

[24] BIS, IS: 13920 Ductile Detailing of Reinforced Concrete Structures Subjected to Seismic Forces - Code of Practice. New Delhi Bureau of Indian Standard, 1993.

[25] ASCE-41, Seismic Rehabilitation of Existing Buildings (ASCE/SEI 41-06). American Society of Civil Engineers: Reston, Virginia, 2007.

[26] A. Madan, A.M. Reinhorn, J.B. Mander, and R.E. Valles, "Modeling of masonry infill panels for structural analysis," $J$. Struct. Eng. ASCE, vol. 123, pp. 1295-1302, 1997.

[27] P.G. Asteris, "Lateral stiffness of brick masonry in filled plane frames," J. Struct. Eng. ASCE, vol. 129, pp. 1071-1079, 2003.

[28] SAP2000, CSI analysis reference manual for SAP2000, ed. Computers and Structures Inc.: Berkeley, California 2010.

Received: December 02, 2011

Revised: April 03, 2012

Accepted: April 04, 2012

(C) Haldar and Singh; Licensee Bentham Open.

This is an open access article licensed under the terms of the Creative Commons Attribution Non-Commercial License (http://creativecommons.org/licenses/by-nc/3.0/) which permits unrestricted, non-commercial use, distribution and reproduction in any medium, provided the work is properly cited. 